\title{
The Influence of Ethical Leadership and Regulatory Focus on Employee Outcomes
}

\author{
Mitchell J. Neubert \\ Cindy Wu \\ James A. Roberts \\ Baylor University
}

\begin{abstract}
Regulatory focus theory is proposed as offering an explanation for the influence of ethical leadership on organizational citizenship behaviors and employee commitments. The prevention focus mindset of an employee is argued to be the mechanism by which an ethical leader influences extra-role compliance behavior as well as normative commitment, whereas the promotion focus mindset of an employee is argued to be the mechanism by which an ethical leader influences extra-role voice behavior as well as affective commitment. Moreover, leader-member exchange is proposed as a moderator of the relationship of ethical leadership to regulatory focus mindsets and employee behavior and commitments. Using the data collected in two waves from 250 working adults, we tested the proposed relationships with moderated mediation bootstrap procedures. The findings generally support the hypothesized relationships and point toward important implications for ethical leadership in work settings.
\end{abstract}

KEY WORDS: ethical leadership, regulatory focus, LMX, organizational commitment, organizational citizenship behavior

$I^{\mathrm{N}}$

N TODAY'S DYNAMIC BUSINESS ENVIRONMENTS, the development of a committed work force that also acts innovatively and works together cooperatively is essential to sustainable organizational effectiveness (Cooper-Hakim \& Viswesvaran, 2005; Choi, 2007; Marinova, Moon, \& Van Dyne, 2010; Mayer, Kuenzi, Greenbaum, Bardes, \& Salvador, 2009; Meyer, 2009; Morrison, 2011). Increasing levels of complexity and dynamism make it difficult for leaders to identify and address problems by themselves; in this context, employees who raise issues and offer suggestions can make significant contributions to organization functioning (Gao, Janssen, \& Shi, 2011). Scholars have explored the influences on these types of employee behavior (e.g., LePine \& Van Dyne, 2001; Marinova et al., 2010) and the bonds of commitment that characterize engaged employees (e.g., Cooper-Hakim \& Viswesvaran, 2005). But questions remain, particularly as it relates to understanding the influence of leadership behavior on employees (Morrison, 2011; Wayne, Coyle-Shapiro, Eisenberger, Liden, Rousseau, \& Shore, 2009).

Ethical leadership, defined as "the demonstration of normatively appropriate conduct through personal actions and interpersonal relationships, and the promotion of such conduct to followers through two-way communication, reinforcement, 
and decision-making" (Brown, Treviño, \& Harrison 2005: 120), has the potential to encourage this type of positive engagement among employees. Ethical leadership encompasses both the morality of duty and obligation to avoid negative behaviors and the morality of aspiration and positive or praiseworthy behaviors (Wiltermuth, Monin, \& Chow, 2010). Ethical leadership reduces the prevalence of negative characteristics of the work environments such as unethical behavior and relationship conflict (Mayer, Aquino, Greenbaum, \& Kuenzi, 2012), and it contributes to the positive characteristics of the work environment such as employees enjoying their jobs (Neubert, Carlson, Kacmar, Roberts, \& Chonko, 2009). From top management trickling down to supervisors, ethical leaders communicate powerfully what is appropriate and preferred behavior (Brown \& Mitchell, 2010; Mayer et al., 2009).

Despite the growing attention on ethics in business, only a small but growing number of empirical studies have examined the outcomes of ethical leadership (Brown et al, 2005; Detert, Treviño, Burris, \& Andiappan, 2007; Mayer et al., 2009; Mayer et al., 2012; Piccolo, Greenbaum, Hartog, \& Folger, 2010; Rubin, Dierdorff, \& Brown, 2010; Walumbwa \& Schaubroeck, 2009; Walumbwa, Mayer, Wang, Wang, Workman, \& Christensen, 2011). Our understanding of the underlying psychological mechanisms of ethical leadership is even more limited (Walumbwa \& Schaubroeck, 2009). In fact, the leadership literature overall has paid relatively little attention to the psychological mechanisms by which the motivational effects of leadership influence followers (Kark \& Van Dijk, 2007). This is unfortunate because studies of such mechanisms can not only better our understanding of ethical leadership but also enhance our knowledge in developing ethical leaders and followers (Brown \& Mitchell, 2010; Walumbwa \& Schaubroeck, 2009; Walumbwa et al., 2011).

Higgins's Regulatory Focus Theory $(1997,1998)$ describes two regulatory foci-prevention and promotion focus - that we utilized as potential psychological mechanisms for explaining leadership influence on others. Regulatory foci are mindsets that reflect the motivational orientation of individuals and that influence behavior. A motivational orientation with the goal of avoiding undesired end-states by minimizing the possible risks or losses is a prevention focus, while a motivational orientation with the goal of approaching desired end-states by maximizing the possible ideals or gains is a promotion focus (Higgins, 1997, 1998). Individuals with a prevention focus mindset tend to be more cautious in their behavior and motivated by a sense of obligation, whereas individuals with a promotion focus mindset tend to be more exploratory in their behavior and motivated by a sense of achievement (Kark \& Van Dijk, 2007). In organizations, empirical evidence is emerging to support leaders as contextual influences that influence employee regulatory foci and employee behaviors (Neubert, Kacmar, Carlson, Chonko, \& Roberts, 2008; Wu, McMullen, Neubert, \& Yi, 2008).

Leadership research also has a rich history of considering variables that moderate the influence of leadership on followers (Avolio \& Bass, 1988; Kerr \& Jermier, 1978). One of the most notable variables in explaining the influence of leaders on followers is the quality of relationship between the leader and those they influence (Sparrowe, Soetjipto, \& Kraimer, 2006). Leader-member exchange (LMX) is a measure of the quality of relationship between leaders and those they influence 
(Graen \& Uhl-Bien, 1995). Although LMX can have a direct positive relationship on employees generally (Gerstner \& Day, 1997; Ilies, Nahrgang, \& Morgeson, 2007), the quality of relationship also interacts with specific leadership behaviors to determine the specific type and magnitude of influence on followers (Sparrowe et al., 2006). We expect that the quality of relationship between leaders and employees has the potential for enhancing the influence of ethical leadership (Brown \& Mitchell, 2010). Specifically, we will argue that high quality LMX relationships enhance the influence of ethical leadership behavior in shaping employees' regulatory foci.

In this paper, we first provide a general theoretical rationale for regulatory foci as mediators of leadership influence on important employee outcomes, and then we propose specific mediating hypotheses explicating the influence of ethical leadership on each regulatory focus and subsequent outcomes. Specifically, we argue that employees' prevention focus will mediate the influence of ethical leadership on employees' extra-role compliance behavior and normative commitment, whereas employees' promotion focus will mediate the ethical leadership influence on employee extra-role voice behavior and affective commitment. Additionally, this study identifies a critical factor, leader-member exchange (LMX), as a moderator of the mediated relationships. This research contributes to the growing literatures related to ethical leadership and regulatory focus by testing the proposed mediating and moderating relationships illustrated in Figure 1.

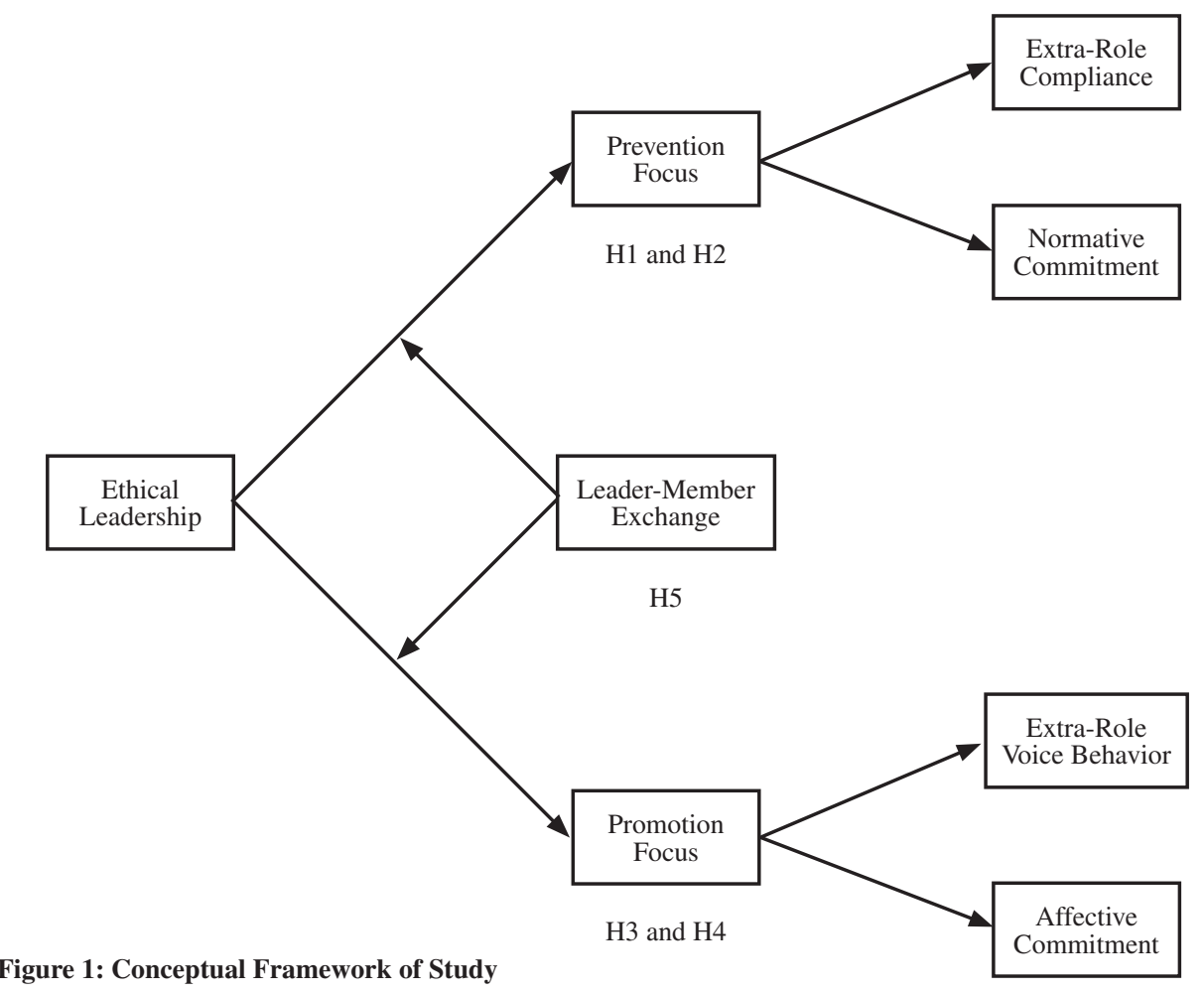




\section{THEORETICAL RATIONALE FOR REGULATORY FOCI AS MEDIATORS}

\section{Regulatory Foci}

Self-regulation lies at the heart of understanding purposeful action and decisions; it mediates "the effects of most external influences" (Bandura, 1991: 248). An individual's regulatory focus is a specific social cognitive explanation of motivation that extends beyond simple base hedonic impulses to include strategic consideration of needs, goals, and outcomes (Higgins, 1997, 1998). The orientation toward attending to security needs, obligations, and losses is a prevention focus, whereas attending to achievement, ideals, and gains is a promotion focus (Higgins, 1997, 1998). These regulatory foci coexist and are activated accordingly in response to different needs, goal pursuits, or salient outcomes (Scholer \& Higgins, 2010). A person also may activate both to some degree because prevention and promotion foci are not mutually exclusive (Higgins, 1997). Meta-analytic research affirms that most antecedent influences are associated with a particular focus, but conscientiousness is an example of an antecedent influence that is associated with both promotion and prevention foci (Lanaj, Chang, \& Johnson, 2012). Thus, conscientiousness is a particularly potent influence on work outcomes because its influence is mediated by both regulatory foci operating in tandem to achieve goals (Lanaj et al., 2012).

Although a person can have an enduring or chronic regulatory focus influenced by personality and early life socialization (Higgins, 1997, 1998), regulatory focus also can be a malleable psychological state that can be primed or evoked by situational cues (e.g., Liberman, Idson, Camacho, \& Higgins, 1999; Friedman \& Förster, 2001; Wallace \& Chen, 2006). A person may have a dominant regulatory focus at any one point in time, but the focus may change in response to situational cues. Higgins $(1997,1998)$ asserted that cues that emphasize security needs, duties or obligations, and avoiding losses tend to elicit a prevention focus mindset, whereas cues that emphasize nurturance needs, aspirations or ideals, and achieving gains tend to elicit a promotion focus mindset. Situationally activated regulatory focus mindsets are significant predictors of attitudes and behaviors (Brockner \& Higgins, 2001; Friedman \& Forster, 2001; Neubert et al., 2008; Wallace \& Chen, 2006). Through their behavioral cues and use of reinforcements, role models, such as caretakers, have been shown to influence the regulatory focus of children (e.g., Higgins \& Silberman, 1998). Similarly, organizational leaders have the potential to shape employees' regulatory focus (Brockner \& Higgins, 2001).

\section{Leadership Influence}

Social cognitive theory (Bandura, 1986, 1991) posits that individuals learn by observing salient role models and directly interacting with role models. In organizations, role models, such as leaders and immediate supervisors, are powerful sources of influence due to their position and authority (Wood \& Bandura, 1989). Leaders are the "makers of meaning" (Brockner \& Higgins, 2001: 58), therefore, employees attend to the cues and the use of language and symbols of leaders to ascertain unwritten expectations (James, James, \& Ashe, 1990; Kark \& Van Dijk, 2007). Additionally, 
due to leaders' power to administer rewards or punishment, organizational members are motivated to attend to leaders' behavior and communication in order to obtain rewards or avoid punishment, making leaders even more influential as role models (Arvey \& Jones, 1985; Bandura, 1986; Treviño, 1992).

Leaders' behavior and interpersonal communications are salient cues shaping adaptive cognitive processes (Brockner \& Higgins, 2001; Kark \& Van Dijk, 2007). Research has demonstrated that leaders can influence the regulatory focus of employees (Neubert et al., 2008; Wu et al., 2008). Through self-regulation, individuals adjust and align their mindsets and behaviors with the expectations or example of leaders (Brockner \& Higgins, 2001; Bandura, 1991). When leaders through their words and example appeal to or reflect the importance of the "ideal self" of hopes, aspirations, and gains, a promotion focus is likely to be activated in employees. Likewise, when leaders emphasize the "ought self" of obligations, responsibilities, and avoiding loss, a prevention focus is likely to be activated in employees (Kark \& Van Dijk, 2007). In turn, an individual's regulatory mindset brings purpose and direction to judgments and intentions such that the resulting behavioral choices and commitments are aligned with a particular cognitive focus (Meyer, Becker \& Vandeberghe, 2004).

Ethical leadership is a particular form of leadership that is distinct from other forms of leadership and has the potential to influence a range of important work outcomes. Ethical leadership includes behaviors such as being trustworthy, inclusive, and fair that reflect being a moral person, and behaviors such as punishing unethical behavior and communicating the importance of ethics that reflect being a moral manager (Brown \& Treviño, 2006; Treviño, Hartman, \& Brown, 2000). While transformational, transactional, and authentic forms of leadership share aspects of these components, only in the case of ethical leadership are these central and necessary components (Bass \& Steidlmeier, 1999; Brown et al., 2005; Kalshoven, Den Hartog, \& Hoogh, 2011; Piccolo et al, 2010). Indeed, in testing the nomological relationships between ethical leadership and other variables, positive correlations exist but also indicate distinctions between these leadership variables (e.g., Brown et al., 2005; Walumbwa, Avolio, Gardner, \& Wernsing, 2008).

In encompassing behavior related to the moral person and moral manager, ethical leadership is unique in affirming both the morality of avoiding negative behaviors and the morality of aspiring to engage in positive behaviors (Wiltermuth et al., 2010). Together, these components of ethical leadership are logically and empirically associated with lower levels of deviance (e.g., Mayer et al., 2009) and relational conflicts (Mayer et al., 2012), but also may be associated with a range of positive work outcomes such as critical in-role and extra-role behaviors and commitments that are critical to organizational functioning.

\section{Focal Outcomes}

Behavioral outcomes of individuals in organizations have been conventionally divided into in-role behaviors (explicitly understood and promoted by organizational authorities as being required for a specific role or job) and extra-role discretionary 
behaviors (those maintaining or improving the social and psychological context of the organization) (Dierdorff \& Morgenson, 2007; Organ \& Konovsky, 1989; Williams \& Anderson, 1991). Of the potential outcomes that regulatory focus may affect, extra-role discretionary behaviors not formally prescribed by organizational roles are of particular importance (LePine \& Van Dyne, 2001) and among the most desired behaviors in the workplace (Choi, 2007). These extra-role behaviors are described as organizational citizenship behavior (OCB) or contextual performance because they contribute indirectly to organizational effectiveness (Borman \& Motowidlo, 1993; Smith, Organ, \& Near, 1983).

OCBs are instrumental to organizational success in that adaptive behaviors spur organizational improvement while affiliative behaviors are essential to maintaining productive work relationships (Choi, 2007; Marinova et al., 2010). OCBs include (1) helping and sportsmanship behaviors that are predominately interpersonal, and (2) voice and compliance behaviors that are directed toward organizational welfare (Marinova et al., 2010). Our interest is in organizationally-directed OCBs, because they contribute to either change and adaptation (through voice behavior) or to stability and maintenance of work relationships (through compliance behavior), both of which are essential to organizational effectiveness (Choi, 2007; Marinova et al., 2010; Mayer et al., 2009; Morrison, 2011; Podsakoff, MacKenzie, Paine, \& Bachrach, 2000).

Besides affecting behaviors, the same psychological mechanisms may also uniquely influence types of commitment to an organization. Commitment has an instrumental role in affecting job satisfaction and performance, withdrawal, and turnover (Cohen, 2003; Cooper-Hakim \& Viswesvaran, 2005; Johnson, Chang, \& Yang, 2010). Commitment has been conceptualized as a bond or attachment to a particular entity, action, or target (Klein, Molloy, \& Cooper, 2009; Salancik, 1977). When the focus is an organization, this commitment is argued to be informed by mindsets that vary in being rooted in desire (i.e., affective commitment), obligation (i.e., normative commitment), or perceived costs and opportunities (i.e., continuance commitment) (Allen \& Meyer, 1990; Meyer \& Allen, 1991, 1997). Whereas continuance commitment is related to external constraints such as alternative employment opportunities, our interest is in the affective and normative commitments that are uniquely influenced by the internal self-regulatory prevention and promotion foci of individuals (Johnson et al., 2010). Further, the motivational base of desire for affective commitment is likely to be associated with the aspiration-orientation of a promotion focus, whereas the motivational base of obligation for normative commitment is likely to be associated with the ought-orientation of prevention focus (Johnson et al., 2010).

Having described the general mediating influence of regulatory foci and identified theoretically relevant employee outcomes, we now narrow our attention to ethical leadership in developing our hypotheses. Furthermore, after proposing the mediating relationships we discuss the moderation of these relationships by LMX. 


\section{HYPOTHESES}

\section{Ethical Leadership, Prevention Focus, and Employee Outcomes}

Ethical leaders are influential role models in organizations who shape attitudes and behaviors (Brown \& Treviño, 2006; Brown et al., 2005; Mayer et al., 2009; Walumbwa et al., 2011) by demonstrating appropriate conduct in their own actions and interactions with others and by promoting ethical conduct by communication, reinforcement, and decision-making (Brown et al. 2005). Ethical leaders are particularly salient in the social learning process because they are credible and attractive role models that also have legitimate authority to shape norms for behavior through the use of rewards and punishments (Mayer et al., 2012). Ethical leadership encompasses a range of behaviors that, depending on the behavior emphasized, can engender predominantly a prevention or promotion focus in others.

Ethical leadership as conceptualized by Brown, Treviño, and Harrison (2005) includes behaviors related to being a moral manager that are transactional in nature such as disciplining employees that act unethically and making fair decisions. Ethical leaders also have been described as being fair, consistent, and trustworthy, preventing harm to others or the environment, and fulfilling one's duty (Ghoshal, 2005; Caza, Barker, \& Cameron, 2004). They engage in transactional efforts to communicate ethical standards, detect and deter deviant behaviors, and make decisions that have important ethical implications (Brown \& Treviño, 2005; Mayer et al., 2009). According to Ciulla (1995), transactional leaders value and promote responsibility, fairness, honesty, and promise keeping. The transactional moral manager aspect of ethical leadership is particularly salient when ethical leaders use rewards and punishments to hold employees accountable for ethical action (Giampetro-Meyer, Brown, Browne, \& Kubasek, 1998; Treviño, Brown, \& Hartmann, 2003).

Regulatory focus theory has suggested that a leader whose behavior orientation is transactional is likely to evoke a prevention mindset of ensuring security, avoiding losses, and fulfilling obligations (Kark \& Van Dijk, 2007). Individuals with a prevention mindset focus on their obligations or duties, allowing a sense of what "ought" to be done to prevail in determining their behavior (Higgins, 1997). They attend to and recall information related to the costs or punishments associated with loss or failure (Higgins \& Tykocinski, 1992). This prevention mindset stemming from the moral manager aspects of ethical leadership produces compliance-oriented vigilant behavior that avoids potential negative outcomes and satisfies explicit expectations or policies (Higgins, Roney, Crowe, \& Hymes, 1994).

Extra-role compliance is associated with attention to adherence to informal norms or unwritten organizational expectations for cooperative relationships (Marinova et al., 2010; Williams \& Anderson, 1991). Specifically, it entails maintaining the status quo, conforming to organizational policies and procedures, fulfilling informal expectations, and protecting organizational interests (Choi, 2007; Marinova et al., 2010; Williams \& Anderson, 1991). Extra-role compliance behavior is particularly important for maintaining efficiency and stability as organizations flatten, increase spans of control, and expand the autonomy of employees (Podsakoff et al., 2000). 
The ethical leader who emphasizes following the rules and ensures accountability contributes to a heightened sense of duty, obligation, and adherence to standards such that employees who are influenced by an ethical leader are likely to adopt a prevention focus and, in turn, exhibit compliance behavior to maintain and reinforce the status quo. Thus,

Hypothesis 1: Prevention focus will mediate the relationship between ethical leadership and employee extra-role compliance behavior.

In addition to influencing discretionary compliance behavior, the prevention focus activated by an ethical leader is likely to be associated with normative commitment to the organization. Normative commitment is the form of psychological attachment to the organization argued to stem from perceived obligations regarding how a person should act or respond toward the organization (Meyer \& Allen, 1991, 1997). The "ought" or moral manager orientation of an ethical leader who emphasizes adherence to ethical standards and holds employees accountable is likely to result in a prevention focus attending to security needs, obligations, and avoiding losses that translates into the feeling of obligation that is the motivational basis of normative commitment (Johnson et al., 2010). Thus,

Hypothesis 2: Prevention focus will mediate the relationship between ethical leadership and employee normative commitment.

\section{Ethical Leadership, Promotion Focus, and Employee Outcomes}

Ethical leaders also model ethical behavior and promote ethical conduct rooted in the moral person aspects of ethical leadership that relate to personal characteristics in interactions (Brown \& Treviño, 2006). Beyond a morality of duty and obligation, this morality is associated with aspirations and going beyond minimal expectations (Wiltermuth et al., 2010). Ethical leaders emphasize employee input, act with the best interest of others in mind, exercise consideration, and allow employees to voice their concerns (Brown et al., 2005). By demonstrating these behaviors, ethical leaders become credible, attractive, and nurturing role models that followers desire to emulate (Mayer et al., 2009).

Ethical leaders also use language and symbols to appeal to moral ideals in interactions with their employees (Piccolo et al., 2010). Moral values and ethical principles are emphasized by ethical leaders as the means to make decisions (De Hoogh \& Den Hartog, 2008). Ethical leaders consciously instill in employees the moral ideals behind tasks and assignments (Thompson \& Bunderson, 2003), promote the achievement of socially responsible goals, and elaborate on how various ethical decisions and tasks benefit the organization and the society (Piccolo et al., 2010). By acting with others interests in mind, communicating moral ideals, challenging others to achieve noble goals, ethical leaders also engender a regulatory focus among employees that is promotion-oriented.

Individuals with a promotion mindset focus on achieving ideals and aspirations and seeking opportunities for growth or advancement (Higgins, 1997). They attend to and recall information related to the benefits or positive outcomes associated with 
gain or success (Higgins, Shah, \& Friedman, 1997; Higgins \& Tykocinski, 1992). This promotion mindset produces exploratory behavior and initiative to achieve the desired positive outcomes, which defy the status quo and surpass minimum expectations (Higgins et al., 1994).

In organizations, employee behaviors that challenge the status quo and suggest improvements and enhancements to organizational practices are voice behaviors (Choi, 2007; Marinova et al., 2010). Van Dyne and LePine (1998: 108) describe voice behavior as one of several promotive citizenship behaviors, which "promote, encourage, or cause things to happen." Generally, voice behavior involves verbal communication or expressions directed toward improving the organization or promoting the interests of an individual or his or her work group. Expressing voice, more specifically, may involve speaking up to address concerns, contributing suggestions for change, and offering opinions even if these opinions conflict with others' opinions or positions (Van Dyne \& LePine, 1998). Voice behavior within organizations is a critical impetus for the innovation, adaptation, and the continuous improvement that is essential to most organizations (LePine \& Van Dyne, 2001).

The ethical leader who demonstrates and communicates moral ideals for behavior while maintaining a personal connection with their employees contributes to a promotion focus in employees that, in turn, encourages a willingness to risk voicing improvements and changes to the status quo. Thus,

Hypothesis 3: Promotion focus will mediate the relationship between ethical leadership and employee extra-role voice behavior.

In addition to influencing discretionary voice behavior, the promotion focus activated by an ethical leader is likely to be associated with affective commitment to the organization. Affective commitment to the organization is the form of psychological attachment based on desire and shared values (Meyer \& Allen, 1991, 1997). In comparison with normative and continuance commitment, affective commitment has stronger associations with job satisfaction and performance and turnover intentions (Cohen, 2003; Cooper-Hakim \& Viswesvaran, 2005). The "aspiration" or moral person orientation of an ethical leader who is inclusive, considerate, and trustworthy is likely to result in a promotion focus of attending to achievement, ideals, and gains that translates into the feeling of desire that is the motivational basis of affective commitment (Johnson et al., 2010). Thus,

Hypothesis 4: Promotion focus will mediate the relationship between ethical leadership and employee affective commitment.

\section{Leader-Member Exchange as a Moderator}

LMX is a measure of the social exchange relationships between leaders and followers with the potential to influence follower behavior and commitments (Dansereau, Graen, \& Haga, 1975; Graen \& Scandura, 1987; Graen \& Uhl-Bien, 1995). Overtime a leader develops a relationship with each employee that is predominantly a high quality or low quality social exchange relationship. High quality exchange relationships are characterized by mutually beneficial interactions between the leader 
and follower whereas in low quality exchange relationships less is given and less is received (Graen \& Scandura, 1987). High quality relationships result in mutual trust and high levels of interactions, whereas low quality relationships result in distrust and low levels of interaction (Graen \& Uhl-Bien, 1995). The quality of the relationship between a leader and follower also can moderate the influence of specific leadership behavior on followers by affecting follower receptivity to a leader's influence (Sparrowe et al., 2006). The existence of and implications for differences in the quality of relationships between ethical leaders and their followers have yet to be fully explored (Brown \& Mitchell, 2010).

In this research, the influence of leaders on the regulatory mindset of employees has been argued to occur through role modeling and interpersonal interactions. In order for a role model to be effective in evoking a particular mindset in employees, the role model must be attractive and trusted (Bandura, 1986; Brockner \& Higgins, 2001; Kark \& Van Dijk, 2007). In high quality social exchange relationships, leaders are attractive and trusted, and therefore, are likely to have greater influence in shaping the regulatory foci of employees. Furthermore, if employees perceive their relationship with the leader to be based on mutual trust and respect, they are more likely to emulate the leader's behavior and develop positive attachments. For example, the quality of social exchanges between leaders and followers has been demonstrated to affect the followers' job satisfaction, task performance, and organizational commitment (Gerstner \& Day, 1997; Hooper \& Martin, 2008). Additionally, a high quality social exchange relationship begets high levels of interaction that increase opportunities for influencing regulatory cognitions and observing behavior and attachments to emulate, whereas low quality social exchange relationships limit these opportunities. Thus,

Hypothesis 5: LMX will moderate the relationships of ethical leadership to both prevention and promotion foci.

\section{METHOD}

\section{Sample}

A sample of participants were recruited with the assistance of i.think inc., a research services company specializing in internet-based information acquisition. The use of such organizations to recruit participants and collect data is increasingly more common in management and organizational research (Judge, Ilies, \& Scott, 2006; Piccolo \& Colquitt, 2006). Using a third party to systematically gather a sample allows for pre-screening potential respondents to ensure the sample accurately represents the population of interest. In this study of adults in the United States, we stipulated that participants be full-time employees of an organization, and have direct and frequent contact with a manager (i.e., no telecommuters). Participants worked in a variety of industries and organizations.

To minimize common method bias, data from participants were collected in two waves, separated by three weeks. The first wave of the survey consisted of questions pertaining to ethical leadership, regulatory focus, and LMX. The second wave of 
the survey included the dependent variables (extra-role compliance, normative commitment, extra-role voice behavior, and affective commitment). Respondents were required to complete both surveys to be eligible for a payment of $\$ 10$. A sample of 250 individuals completed both surveys. The composition of the sample was 68 percent $(n=170)$ male and 32 percent female $(n=80)$, and 83 percent $(n=207)$ of the respondents indicated Caucasian ethnicity. Across the whole sample, the average age was 40.44 years and participants averaged 6.2 years spent in their current job.

\section{Measures}

Unless otherwise indicated, all measures used a five-point Likert scale where $1=$ "strongly disagree" and 5 = "strongly agree." We averaged items within a scale to create a composite measure for each variable. Items were coded such that high scores equate to high levels of the construct of interest.

\section{Time 1 Measures}

Ethical Leadership

We used Brown et al.'s (2005) ten-item ethical leadership scale in this study to assess the respondent's view of his or her leader. An example item is, "My supervisor makes fair and balanced decisions." The Cronbach alpha for this scale was .95.

\section{Promotion and Prevention Focus}

We used the eighteen-item Work Regulatory Focus (WRF) measure developed and validated by Neubert et al. (2008) to assess the respondent's regulatory focus. Nine items pertained to prevention focus and nine items pertained to promotion focus. An example item of prevention focus is, "I focus my attention on avoiding failure at work." The Cronbach alpha for prevention focus was .91. An example item of promotion focus is, "I take chances at work to maximize my goals for advancement." The Cronbach alpha for promotion focus was .92 .

Leader-Member Exchange

Scandura, Graen, \& Novak's (1986) seven-item LMX measure was adopted to assess leader-member exchange. An example item is, "My supervisor understands my problems and needs." The Cronbach alpha was .95.

\section{Time 2 Measures}

Extra-Role Compliance Behavior

We used Williams and Anderson's (1991) seven-item scale focused on organizationally-oriented generalized compliance to measure extra-role compliance behavior. An example item is, "I adhere to informal rules devised to maintain order." The Cronbach alpha was .73.

\section{Normative Commitment}

We adopted Meyer and Allen's (1991) six-item measure to assess employee normative commitment. An example item is, "I would not leave my organization right now because I have a sense of obligation to the people in it." The Cronbah alpha was .91. 
Extra-Role Voice Behavior

We used Van Dyne and LePine's (1998) six-item measure to assess extra-role voice behavior. An example item is, "I develop and make recommendations concerning issues that affect this work group." The Cronbach alpha was .95.

\section{Affective Commitment}

Meyer and Allen's (1991) affective organizational commitment scale, consisting of eight items, was used in our study. An example item is, "This organization has a great deal of personal meaning for me.” The Cronbach alpha was .89.

\section{Analyses}

We followed Kenny, Kashy, and Bolger's (1998) procedure to test the proposed mediation between ethical leadership, regulatory focus, and outcome variables. (Hypotheses 1 through 4). Specifically, Kenny et al. (1998) suggested that four conditions need to be met for mediation. First, the independent variable (i.e., ethical leadership) is significantly related to the mediator (i.e., prevention focus and promotion focus). Second, the independent variable is significantly related to dependent variables. Kenny et al. (1998), however, also noted that this relationship could be weak or non-significant if the independent variable is more distal. Third, the mediator must be related to the dependent variables. Fourth, the relationship between the independent and the dependent variables becomes non-significant when the mediator variable is introduced into the equation. If the relationship between independent and dependent variables is reduced but remains significant when the mediator is present, partial mediation is established.

Hypothesis 5 proposed moderated mediation where the influence of ethical leadership on employee outcomes through regulatory foci is moderated by LMX. That is, the hypothesized mediation model remains robust for the overall sample, yet the manners in which the mediation model functions vary by different levels of LMX. Edwards and Lambert (2007) identified a number of shortcomings of various conventional approaches to testing the combination of mediation and moderation, including the violation of multivariate normality of the error terms distribution, and suggested a bootstrapping procedure to overcome these shortcomings. The bootstrap procedure estimates variability in parameter estimates from the dataset by re-sampling with replacement and therefore the derived standard errors do not depend on multivariate normality required by the maximum likelihood estimate method (Bollen \& Stine, 1990).

Although we hypothesized that the moderation takes place between the independent variable and mediator, in our analyses, we used the total effect moderation model that incorporated the moderator between both the independent variable and mediator, and the mediator and outcome. Edwards and Lambert (2007) contended that "unless moderation is tested for each path, hypotheses concerning the moderating effects of $Z$ are shielded from potentially disconfirming evidence" (p. 6) because the moderating effect on one path could change with the inclusion of terms representing another path in the model. Therefore, by using the total effect moderation model, we controlled for the potential nuisances in the path model. 
We incorporated the bootstrap procedure in the multigroup structural equations modeling (SEM) to first examine the overall path model fit. Then, by mean splitting the sample in multigroup SEM, we further examined whether there was a significant difference in the path coefficients between the high and low LMX groups. The bootstrap procedure generated bias-corrected confidence intervals around the path coefficient estimates. If these paths vary across different levels of a moderator (in our case, LMX), there is evidence for moderation.

\section{RESULTS}

\section{Preliminary Analyses}

The means, standard deviations, and correlations among study variables are reported in Table 1. Before testing out hypotheses, we conducted confirmatory factor analyses (CFAs) on ethical leadership, LMX, prevention focus, and promotion focus to ensure that the items captured the constructs adequately and that they generated the expected structure. In addition, because these four variables were collected from the same source at the same time point, we conducted discriminant validity analyses following Fornell and Larcker's procedures (1981) to ensure that the individual items pertaining to one factor converged, and that the four factors were distinct from one another. We used AMOS 7.0 with a maximum likelihood estimation for CFAs and discriminant validity analyses.

We first conducted a four-factor baseline model with CFA that included ethical leadership, LMX, prevention focus, and promotion focus. The ten items of ethical leadership were loaded on one factor, and the seven items of LMX were loaded on another factor. For regulatory focus, we formed three subfactors based on theory for prevention focus representing security, oughts, and losses, and three subfactors for promotion focus representing achievement, ideals, and gains. Fit indices showed that the four-factor model was marginally adequate $\left(\chi^{2}=700.02\right.$, df $=224, p<.01$, $\mathrm{CFI}=.91, \mathrm{TLI}=.90, \mathrm{IFI}=.91, \mathrm{RMR}=.05, \mathrm{RMSEA}=.09)$. To further test whether regulatory focus, ethical leadership, and LMX were distinct factors, we tested one three-factor model that combined LMX with ethical leadership, and three alternative two-factor models with various combinations (see Table 2, p. 282). Finally, to test whether one single common factor dominated the correlational results among these variables of interest, we combined all of them, loaded all the items on one factor

Table 1: Zero-Order Correlations and Descriptive Statistics for the Study Variables

\begin{tabular}{|c|c|c|c|c|c|c|c|c|c|c|}
\hline Variables & $M$ & $S D$ & 1 & 2 & 3 & 4 & 5 & 6 & 7 & 8 \\
\hline 1. Ethical leadership & 3.58 & .93 & .82 & & & & & & & \\
\hline 2. Prevention focus & 4.13 & .65 & $.37 * *$ & .92 & & & & & & \\
\hline 3. Promotion focus & 3.64 & .76 & $.46^{* *}$ & $.52^{* *}$ & .91 & & & & & \\
\hline 4. LMX & 3.61 & 1.00 & $.68 * *$ & $.20 * *$ & $.34 * *$ & .95 & & & & \\
\hline 5. Extra-role compliance & 4.19 & .59 & .12 & $.31^{* *}$ & $.25^{* *}$ & $.16^{* *}$ & .73 & & & \\
\hline 6. Normative commitment & 3.12 & 1.04 & $.48 * *$ & $.29 * *$ & $.30 * *$ & $.46^{* *}$ & $.20 * *$ & .91 & & \\
\hline 7. Extra-role voice behavior & 3.78 & .89 & $.33 * *$ & $.24 * *$ & $.51 * *$ & $.42 * *$ & $.32 * *$ & $.30 * *$ & .95 & \\
\hline 8. Affective commitment & 3.32 & .90 & $.50 * *$ & $.21^{* *}$ & $.34 * *$ & $.51^{* *}$ & $.31 * *$ & $.78^{* *}$ & $.42 * *$ & .89 \\
\hline
\end{tabular}

Note. Internal reliabilities are on the diagonal, in parentheses $(n=250)$. LMX: Leader-member exchange. ${ }^{*} p<.05, * * p<.01$. 
and tested its model fit against the four-factor baseline model. As shown in Table 2 , the results indicate that the baseline four-factor model fit the data satisfactorily, and significantly better than other alternative models.

Next, following Fornell and Larcker's (1981) suggestions for testing convergent and discriminant validity, we first examined the factor loading on each item. Factor loadings greater than .5 provide evidence of convergent validity, indicating the items capture the unobservable factor adequately. All of the item factor loadings were greater than .5, confirming convergent validity. Fornell and Larcker also suggested that there is evidence for discriminant validity if the square root of the average variance explained (AVE) for the two variables of interest exceeds the corresponding correlation between the two factors. We found that all the estimates of square root of AVEs were greater than the corresponding correlations among the variables of interest (square root of AVE $=68, .51, .69, .73$ for ethical leadership, prevention focus, promotion focus, and LMX respectively, and see the correlation coefficients reported in Table 1 for comparison). These statistical results suggest that ethical leadership, prevention focus, promotion focus, and LMX were distinct variables.

Table 2: Comparison of Measurement Models

\begin{tabular}{|c|c|c|c|c|c|c|c|c|c|}
\hline Model & Factors & $\chi^{2}$ & $d f$ & $\begin{array}{c}\Delta \chi^{2} \text { (difference } \\
\text { in d.f.) }\end{array}$ & CFI & TLI & IFI & RMR & RMSEA \\
\hline $\begin{array}{l}\text { Baseline } \\
\text { model }\end{array}$ & $\begin{array}{l}\text { Four factors: eth- } \\
\text { ical leadership, } \\
\text { LMX, prevention } \\
\text { focus, promotion } \\
\text { focus }\end{array}$ & $700.02 * *$ & 224 & & .91 & .90 & .91 & .05 & .09 \\
\hline Model 1 & $\begin{array}{l}\text { Three factors: } \\
\text { promotion focus, } \\
\text { prevention focus, } \\
\text { and ethical lead- } \\
\text { ership + LMX } \\
\text { combined }\end{array}$ & $1455.46^{* *}$ & 227 & $755.44(3) * *$ & .77 & .74 & .77 & .11 & .15 \\
\hline Model 2 & $\begin{array}{l}\text { Two factors: } \\
\text { ethical leader- } \\
\text { ship + LMX } \\
\text { combined and } \\
\text { prevention focus } \\
\text { + promotion } \\
\text { focus combined }\end{array}$ & $1459.17 * *$ & 229 & $759.15(5)^{* *}$ & .77 & .75 & .77 & .11 & .15 \\
\hline Model 3 & $\begin{array}{l}\text { Two fac- } \\
\text { tors: ethical } \\
\text { leadership and } \\
\text { promotion focus } \\
\text { + prevention } \\
\text { focus + LMX } \\
\text { combined }\end{array}$ & $1484.97 * *$ & 229 & $784.95(5)^{* *}$ & .77 & .74 & .77 & .10 & .15 \\
\hline Model 4 & $\begin{array}{l}\text { Two factors: } \\
\text { LMX and ethical } \\
\text { leadership + pro- } \\
\text { motion focus + } \\
\text { prevention focus } \\
\text { combined }\end{array}$ & $1387.27 * *$ & 229 & $687.25(5)^{* *}$ & .78 & .76 & .78 & .08 & .14 \\
\hline Model 5 & $\begin{array}{l}\text { One factor: ethi- } \\
\text { cal leadership + } \\
\text { LMX + promo- } \\
\text { tion focus + } \\
\text { prevention focus } \\
\text { all combined }\end{array}$ & $2147.06^{* *}$ & 230 & $1447.04(6)^{* *}$ & .64 & .61 & .64 & .12 & .18 \\
\hline
\end{tabular}




\section{Treatment of Common Method Variance (CMV)}

Although the data was collected in two waves, all our data came from one common source. As such, we intentionally designed the survey in accordance with suggestions by Podsakoff, MacKenzie, Lee, \& Podsakoff (2003) to decrease priming effects, evaluation apprehension, and socially desirable responses that might contribute to common method variance. We also examined the potential influence of CMV statistically. First, we tested a one-factor model consisting of all the measurement items and estimated the fit of a model with CMV as the dominating latent factor. This one-factor model fit the data poorly $\left(\chi^{2}=7279.70, \mathrm{df}=1175, \mathrm{p}<.01\right.$; $\mathrm{CFI}=$ $.42 ; \mathrm{TLI}=.39 ; \mathrm{IFI}=.42 ; \mathrm{RMR}=.18 ; \mathrm{RMSEA}=.14)$. Next, we estimated a full measurement model that included all eight variables in our study. The fit indices of the full measurement model were not ideal, but not far from the acceptable range $\left(\chi^{2}=\right.$ 2825.96, $\mathrm{df}=1147, \mathrm{p}<.01 ; \mathrm{CFI}=.84 ; \mathrm{TLI}=.83 ; \mathrm{IFI}=.84 ; \mathrm{RMR}=.08 ; \mathrm{RMSEA}=$ .07).Then, we estimated a nine-factor model that included a latent CMV factor in addition to the eight study variables. This model with the CMV factor seemed to fit the data slightly better $\left(\chi^{2}=2368.28, \mathrm{df}=1097, \mathrm{p}<.01 ; \mathrm{CFI}=.88\right.$; $\mathrm{TLI}=.86$; $\mathrm{IFI}=.88 ; \mathrm{RMR}=.07 ; \mathrm{RMSEA}=.07)$ compared to the full measurement model $\left(\chi_{\text {diff }}^{2}(28)=4453.74, p<.01\right)$, but only 4 percent of the variance was accounted for by CMV, much lower than the 25 percent observed by Williams, Cote, and Buckley (1989). Further, all of the factor loadings of study variables remained at the same level of significance $(\mathrm{p}<.01)$ with or without the CMV factor in the model. Consequently, we believe that CMV is not a serious concern and more importantly, the relationships observed are not due to CMV artifacts but represent substantial effects.

\section{Hypotheses Testing}

Hypotheses 1 and 2 proposed that prevention focus would mediate the influence of ethical leadership on extra-role compliance behavior (H1) and normative commitment (H2). Following Kenny et al.'s (1998) procedure to test mediation, we first regressed prevention focus on ethical leadership and found statistical significance $(b=.38$, $\mathrm{p}<.01$, Step 1 in Table 3). Next, we regressed extra-role compliance and normative commitment in two separate equations on ethical leadership. We found that extra-role compliance was marginally significant with ethical leadership $(\beta=.12, \mathrm{p}=.06)$ and normative commitment was significantly related to ethical leadership $(\beta=.48, \mathrm{p}<.01)$.

Table 3: Regression Analyses for Mediation: Prevention Focus as the Mediator

\begin{tabular}{lc|cc|cc} 
& \multicolumn{2}{c}{ DV: Compliance } & \multicolumn{2}{c}{ DV: Normative Commitment } \\
\hline & $\begin{array}{c}\text { Step 1 } \\
\text { IV } \rightarrow \text { Med }\end{array}$ & $\begin{array}{c}\text { Step 2 } \\
\text { IV } \rightarrow \text { DV }\end{array}$ & $\begin{array}{c}\text { Step 3 } \\
\text { IV/Med } \rightarrow \text { DV }\end{array}$ & $\begin{array}{c}\text { Step 2 } \\
\text { IV } \rightarrow \text { DV }\end{array}$ & $\begin{array}{c}\text { Step 3 } \\
\text { IV/Med } \rightarrow \text { DV }\end{array}$ \\
\hline $\begin{array}{l}\text { Independent Variable } \\
\text { Ethical Leadership }\end{array}$ & $.38^{* *}$ & $.12^{+}$ & .00 & $.48^{* *}$ & $.43^{* *}$ \\
$\begin{array}{l}\text { Mediator } \\
\text { Prevention Focus }\end{array}$ & & & & \\
$\begin{array}{l}\text { Adjusted } \boldsymbol{R}^{\mathbf{2}} \\
\boldsymbol{F}(\mathbf{d f})\end{array}$ & .14 & .01 & $.31^{* *}$ & .09 & $.13^{*}$ \\
\hline
\end{tabular}

$\mathrm{N}=250 .{ }^{+} \mathrm{p}<.10 .{ }^{*} p<.05 . * * p<.01$.

Note: Standardized Betas are shown. IV = Independent Variable. DV = Dependent Variable. Med = Mediator. 
In regressing extra-role compliance and normative commitment on ethical leadership and prevention focus, we found that prevention focus was significant for both cases ( $\beta=.31, p<.01$, and $\beta=.13, p<.05$, respectively). Lastly, with prevention focus in the regression equation, the influence of ethical leadership became non-significant on extra-role compliance $(\beta=.00, \mathrm{p}>.05)$, supporting full mediation, whereas the influence remained significant but was reduced on normative commitment ( $\beta=$ $.43, \mathrm{p}<.01$, from .48 without prevention focus in the equation), supporting partial mediation. The significant results from Sobel (1982) tests for extra-role compliance $(\mathrm{z}=3.79, \mathrm{p}<.01)$ and normative commitment $(\mathrm{z}=2.00, \mathrm{p}<.05)$ further confirmed the significant indirect effect (i.e., reduction in the effect of the initial variable on the outcome), lending additional support to mediation. Taken together, these results suggest that prevention focus fully mediates the influence of ethical leadership on extra-role compliance (H1) and partially mediates the ethical leadership-normative commitment relationship (H2). These results are summarized in Table 3.

Hypotheses 3 and 4 stated that promotion focus would mediate the influence of ethical leadership on employee extra-role voice behavior affective commitment. Similar to testing the mediating role of prevention, we also followed Kenny et al's (1998) procedure to examine these hypotheses. First, we regressed promotion focus on ethical leadership and found statistical significance $(\beta=.45, \mathrm{p}<.01$, Step 1 in Table 4). Next, we regressed extra-role voice behavior and affective commitment in two separate equations on ethical leadership. Ethical leadership was significantly related to both $(\beta=.33, \mathrm{p}<.01$, for voice, and $\beta=.50, \mathrm{p}<.01$, for affective commitment). Then, we included the mediator (promotion focus) and the independent variable (ethical leadership) in the regression equations with extra-role voice behavior and affective commitment as the outcome variables. We found that promotion focus was significantly related to extra-role voice behavior and affective commitment ( $\beta=.45, \mathrm{p}<.01$, and $\beta=.17, \mathrm{p}<.05$, respectively). Lastly, with promotion focus in the regression equation, the influence of ethical leadership remained significant, yet reduced, on voice (to $\beta=.13, \mathrm{p}<.05$, from $\beta=.33, \mathrm{p}<.01$, without promotion focus in the equation) and affective commitment (to $\beta=.42, \mathrm{p}<.01$, from $\beta=.50$, $\mathrm{p}<0.1$, without promotion focus in the equation). The significant results from Sobel (1982) tests $(\mathrm{z}=5.42, \mathrm{p}<.01$ for voice behavior, and $\mathrm{z}=2.31, \mathrm{p}<.05$ for affective commitment) further confirmed that the reduction in the effects of the initial vari-

Table 4: Regression Analyses for Mediation: Promotion Focus as the Mediator

\begin{tabular}{|c|c|c|c|c|c|}
\hline & & \multicolumn{2}{|c|}{ DV: Extra-role Voice } & \multicolumn{2}{|c|}{ DV: Affective Commitment } \\
\hline & $\begin{array}{c}\text { Step 1 } \\
\text { IV } \rightarrow \text { Med }\end{array}$ & $\begin{array}{c}\text { Step } 2 \\
\text { IV } \rightarrow \text { DV }\end{array}$ & $\begin{array}{c}\text { Step } 3 \\
\text { IV/Med } \rightarrow \text { DV }\end{array}$ & $\begin{array}{c}\text { Step 2 } \\
\mathbf{I V} \rightarrow \text { DV }\end{array}$ & $\begin{array}{c}\text { Step 3 } \\
\text { IV/Med } \rightarrow \text { DV }\end{array}$ \\
\hline \multicolumn{6}{|l|}{ Independent Variable } \\
\hline Ethical Leadership & $.45^{* *}$ & $.33 * *$ & $.13 *$ & $.50 * *$ & $.42 * *$ \\
\hline \multicolumn{6}{|l|}{ Mediator } \\
\hline Promotion Focus & & & $.45^{* *}$ & & $.17 *$ \\
\hline Adjusted $R^{2}$ & .20 & .11 & .27 & .25 & .26 \\
\hline$F(d f)$ & $63.42(248)^{* *}$ & $30.16(248)^{* *}$ & $46.24(247)^{* *}$ & $83.99(248)^{* *}$ & $45.75(247)^{* *}$ \\
\hline
\end{tabular}

$\mathrm{N}=250 * p<.05 * * p<.01$.

Note: Standardized Betas are shown. IV = Independent Variable. DV = Dependent Variable. Med = Mediator. 
able on the outcomes was significant, lending support to partial mediation. Taken together, these results suggest that promotion focus partially mediates the ethical leadership influence on extra-role voice behavior and affective commitment. These results are illustrated in Table 4.

Hypothesis 5 proposed that LMX would moderate the relationship between ethical leadership and outcome variables that were mediated by regulatory foci. The satisfactory overall model fit in the multigroup SEM suggested that the path model fit the data well across high and low LMX groups $\left(\chi^{2}=30.12\right.$, df $=16, \mathrm{p}<.05$, $\mathrm{CFI}=.97, \mathrm{TLI}=.931, \mathrm{IFI}=.98, \mathrm{RMR}=.05, \mathrm{RMSEA}=.06)$. We therefore further examined and plotted the path diagrams across the high and low LMX groups using the mean split method.

Figures 2 and 3 illustrate the path coefficients generated by SEM for the high versus low LMX groups (with standard errors in parentheses next to each path coefficient). For the high LMX group (Figure 2), all the path coefficients were significant at the .05 level or lower. In contrast, most of the path coefficients except for two (promotion focus to voice behavior, and prevention focus to compliance behavior) were non-significant at the .05 level for the low LMX group (Figure 3, p. 286). When comparing each path across the two LMX groups, we found that the path coefficients between ethical leadership and both regulatory foci were significantly different across the groups at the .01 level. Further, all the indirect effects from ethical leadership to the four outcome variables for the high LMX group were

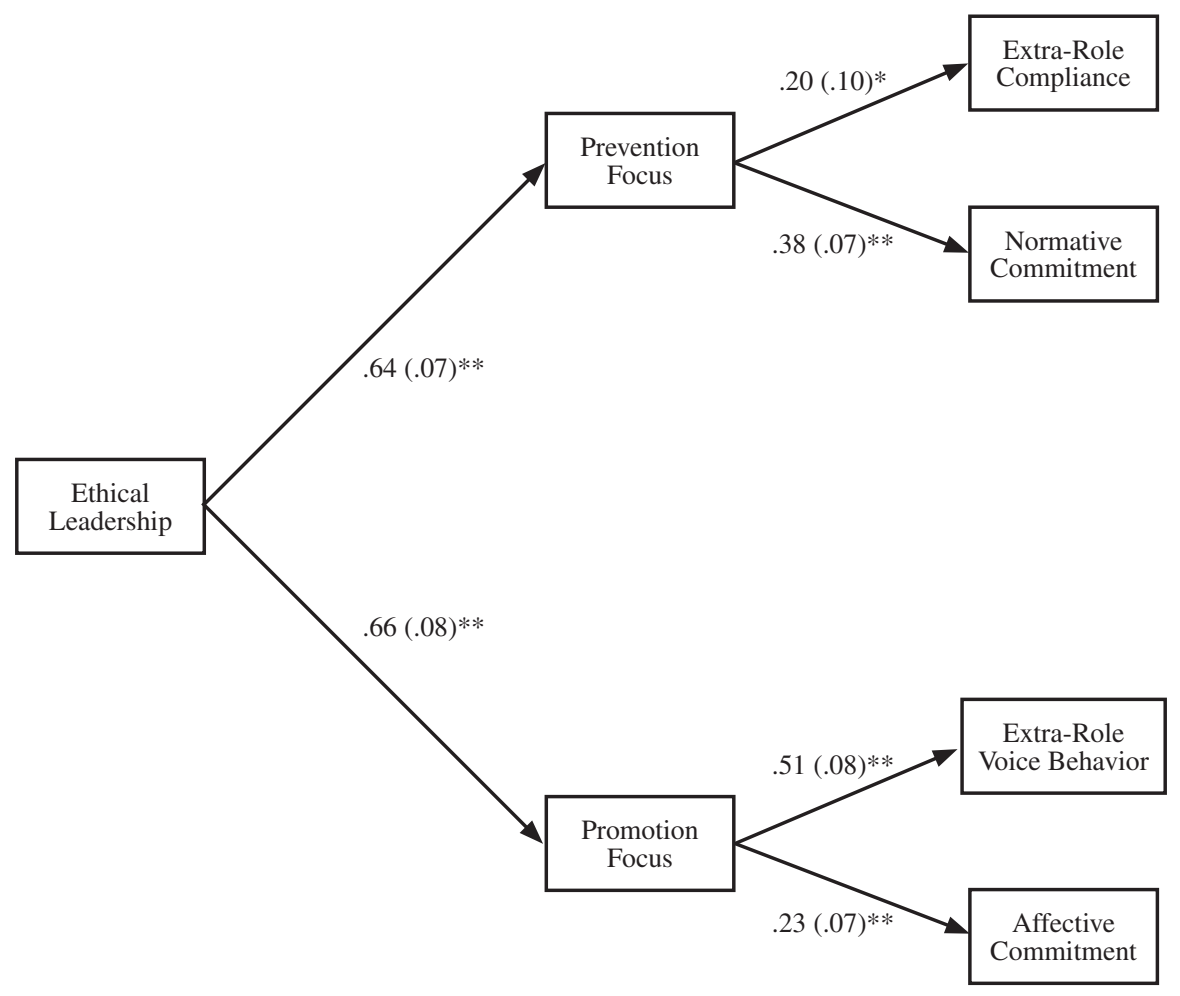

Figure 2: Multigroup SEM Bootstrapping Result for High LMX group.

Unstandardized path coefficients. Standard error in parentheses. **p $<.01 ; * \mathrm{p}<.05$ 


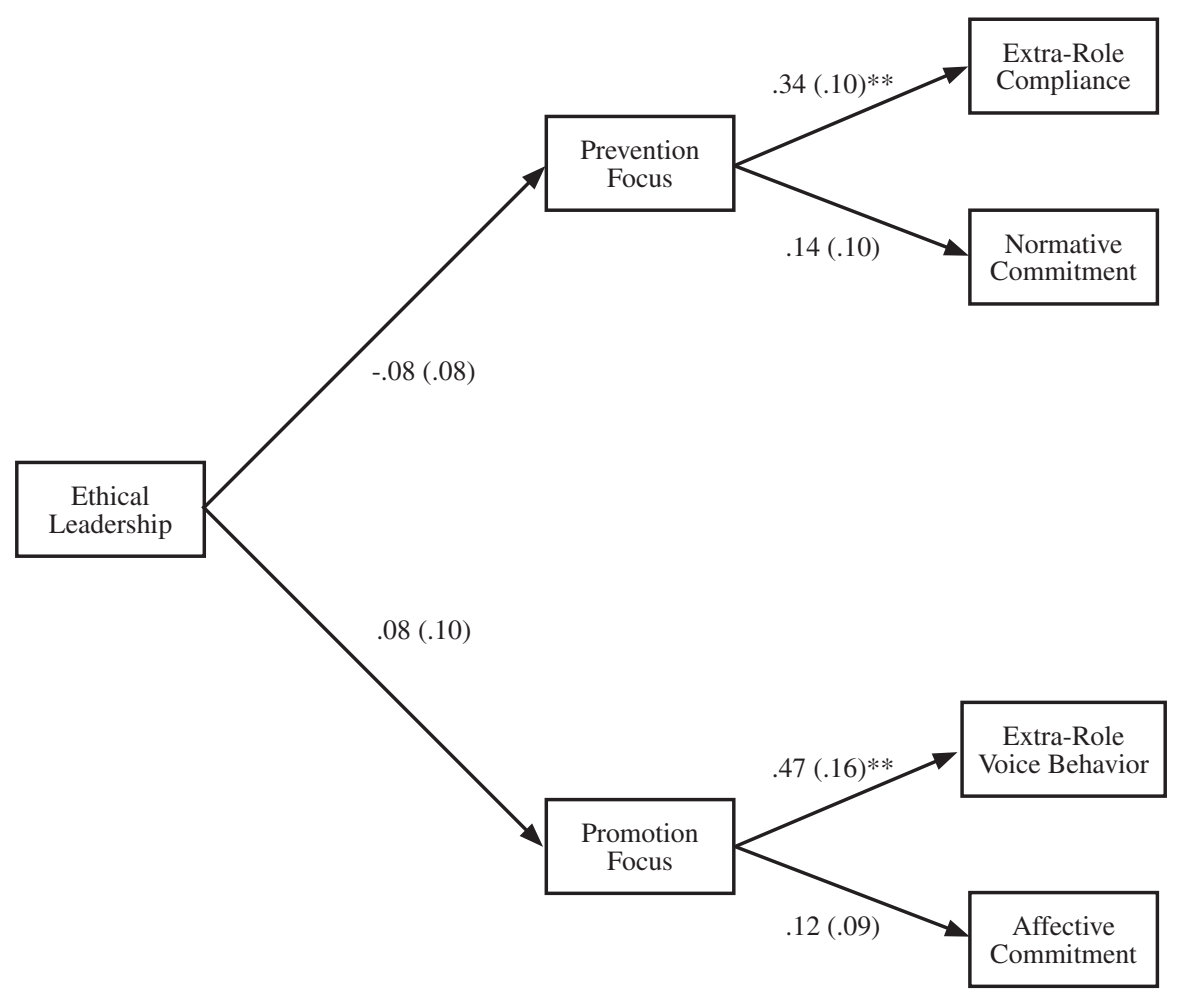

Figure 3: Multigroup SEM Bootstrapping Result for Low LMX group.

Unstandardized path coefficients. Standard error in parentheses. ${ }^{*} \mathrm{p}<.05, * * \mathrm{p}<.01$

significant at the .01 level, whereas none of the indirect effects were significant for the low LMX group. These results suggest that the path model depicting regulatory foci as the mediating mechanisms fits the data well overall. The influence of ethical leadership, however, was mediated differently as a function of LMX. For those with high LMX, ethical leadership influenced their extra-role voice behavior and affective commitment through enhanced promotion focus, and their extra-role compliance behavior and normative commitment through enhanced prevention focus. But for those with low LMX, none of these mediating processes were found. These findings support moderated mediation, lending support to Hypothesis 5.

\section{DISCUSSION}

There is increasing recognition of the importance of understanding what contributes to a committed workforce that can work collaboratively and respond to and adapt effectively to rapidly changing business environments (e.g., Gao et al., 2011; Marinova et al., 2010; Meyer, 2009; Morrison, 2011). In addition to its traditional role in deterring unethical or counterproductive behavior (Mayer et al., 2012), ethical leadership is gaining support as a leadership style that also influences positive or productive behavior and attachments (Kalshoven et al., 2011; Mayer et al., 2009; Neubert et al., 2009; Walumbwa et al., 2011). Yet, research explaining the underlying 
psychological mechanisms by which ethical leadership has its influence is limited (Walumbwa et al., 2011).

Our study addresses this lacuna in this emerging stream of research by empirically examining how regulatory foci mediate the influence of ethical leadership on employee behavior and commitments. Specifically, we found that ethical leadership influences extra-role compliance behavior and normative commitment, in part, through evoking employees' prevention focus. Additionally, ethical leadership influences extra-role voice behavior and affective commitment, in part, through evoking employees' promotion focus. Furthermore, our research found that LMX is a moderator of these mediated relationships, particularly as it relates to the influence of ethical leadership in shaping regulatory foci. When LMX indicates a high quality relationship, ethical leaders have a strong influence on promotion focus and prevention focus in employees, whereas when LMX indicates a low quality relationship there is not a significant influence of ethical leadership on regulatory foci.

Altogether our findings have important practical and theoretical implications. First, a key contribution of this research is in demonstrating that ethical leadership can play a role in positively influencing employees beyond the limited role of deterring unethical behavior. According to our research, ethical leaders can influence the extent to which employees voice suggestions for improvement, devote themselves to maintaining cooperative relationships, and commit to the organization. Practically, this research helps substantiate the value of ethical leadership and the scope of positive ways it influences members of the organization. In combination with research linking ethical leadership with performance (Walumbwa et al., 2011), this research augments the case for selecting, developing, and promoting ethical leaders.

Second, by finding that regulatory foci at least partially mediate the influence of ethical leadership on employee outcomes, we affirm theory proposing regulatory foci as social psychological mechanisms that explain the influence of leaders on employees (Brockner \& Higgins, 2001; Kark \& Van Dijk, 2007) and extend it to ethical leadership. Although this assertion about leadership has recently been supported (e.g., Neubert et al., 2008; Wu et al., 2008), to our knowledge there have been no tests of the association of ethical leadership with regulatory foci and employee outcomes. Consistent with the common assertion that ethical leaders influence followers through role modeling of particular behaviors (Brown \& Treviño, 2006), our research demonstrates that ethical leadership behavior is associated with self-regulatory processes that influence employee commitments and organizational citizenship behavior. Following from these results, theory utilizing regulatory foci has the potential to explain how ethical leadership may influence other discretionary behavior such as whether or not employees engage in forms of socially responsible behavior. For example, socially responsible behavior that preserves natural resources would seem to be associated with a prevention focus whereas socially responsible behavior that contributes to the growth or benefit of community members would seem to be associated with a promotion focus.

A third implication of our findings relates to supporting LMX as a moderator of the mediated relationships in the study. As Wallace and Chen noted, because of the lack of empirical studies in the work setting, "additional research is needed to more 
fully understand how individual differences and organizational influences uniquely and simultaneously influence one's regulatory focus and performance at work." (Wallace \& Chen, 2006: 535). Indeed, although tests of regulatory focus theory in work settings have emphasized the potential for leaders to serve as role models in eliciting particular regulatory mindsets (Neubert et al., 2008; Wu et al., 2008), the situational factors that might moderate the social cognitive influence of leaders on employees have been largely unexplored. By demonstrating that LMX moderates the relationship of ethical leadership to regulatory mindsets, we extend theory to include situational factors and affirm a common sense maxim that leadership influence is stronger in the context of quality relationships. In other words, the leader who establishes and nurtures relationships based on respect, support, and trust (high LMX) has a stronger influence on the mindsets of employees than the leader who is perceived as distant, detached, and distrustful (low LMX).

\section{Limitations and Future Directions}

In choosing to explore a situational factor, we did forgo the opportunity to test for individual differences that might moderate the influence of leaders on followers. Specifically, Higgins (2000) has proposed that individuals may respond to stimuli in part due to their chronic or dispositional regulatory fit. In this case, the individual difference associated with the chronic regulatory focus of an individual may moderate the influence of ethical leadership on situational regulatory foci. For example, those predisposed to a prevention focus may develop a situational prevention focus when exposed to the behavior of an ethical leader, whereas those predisposed to a promotion focus may develop a situational promotion focus when exposed to an ethical leader. This is a question for future research.

Although the proposed mediated relationships were supported, particularly in the context of high quality LMX relationships, finding partial mediation suggests that self-regulatory processes are important, but not exclusive explanations for the influence of ethical leadership on employee behavior and commitments. Ethical leadership has an influence on other related but distinct psychological processes such as the development of organizational identification and self-efficacy (Walumbwa et al., 2011) and perceptions of the organization's climate (Neubert et al., 2009). Future theory and research is needed that explicates the potential influence of ethical leadership on other psychological mechanisms that might to contribute to other follower outcomes. Moreover, to supplement research findings of the effects of ethical leadership on group-level behaviors (Mayer et al., 2009), more group-level psychological phenomena also should be explored.

Another finding with relevance to theory development and future research is that ethical leadership is associated with both prevention and promotion foci. Whereas most leadership styles have been theorized to induce either promotion or prevention focus (e.g., Kark \& Van Dijk, 2007; Neubert et al., 2008), ethical leadership was proposed as encompassing behavior related to being both a moral manager and moral person, and, therefore, may induce both regulatory foci to some degree. Empirical support for this assertion extends research on regulatory focus by demonstrating 
that one leadership style can evoke both mindsets. Previous research indicated that conscientiousness also is associated with both mindsets (Lanaj et al., 2012; Wallace \& Chen, 2006). Together, these findings support Higgins's $(1997,1998)$ early theoretical argument that prevention focus and promotion focus are independent but not mutually exclusive constructs. Perhaps, ethical leadership evokes each mindset at different points in time, depending on which of the behaviors exhibited by the leader are most prominent at that time. In other words, over time the ethical leader's behavior may be generally viewed as both promotion-oriented and prevention-oriented despite differences in behavioral emphasis on a moment by moment basis, and, thus, ethical leadership positively influences both regulatory foci of employees. Future research should explore these assertions by assessing behavior and mindsets longitudinally. Despite measuring our independent and dependent variables at separate points in time, a limitation of our research is that we cannot address questions related to the influence of ethical behavior on employee mindsets across time.

The dual influence of ethical leadership on promotion and prevention foci also raises a question of whether ethical leadership is multidimensional. Wallace and Chen (2006) proposed that the influence of conscientiousness on both regulatory foci may be due to the facets of conscientiousness. Similarly, ethical leadership may have facets while at the same time demonstrating the unity of being based on the same higher order construct. Despite evidence from our study and others (e.g., Piccolo et al., 2010; Walumbwa et al., 2011) that the Brown et al. (2005) measure can be characterized as unidimensional, some researchers using other measures of ethical leadership have found ethical leadership to be multidimensional (e.g., De Hoogh \& Den Hartog, 2008; Kalshoven et al., 2011). Future research should compare measures of ethical leadership to address the issue of potential multidimensionality, but it also should assess the relationship of ethical leadership to regulatory mindsets and employee outcomes over time.

We found ethical leadership to be a significant influence on employee behavior and commitment. Yet, an organization's ethical infrastructure includes both informal (e.g., group norms) and formal (e.g., codes and policies) components that deter unethical or counterproductive behavior and that promote ethical or productive behavior (Tenbrunsel, Smith-Crowe, \& Umphress, 2003; Weaver, Treviño, \& Cochran, 1999). Combinations of informal and formal components of the organization's ethical infrastructure should be explored to more fully understand employee behavior and commitments. For example, if formal components of the ethical infrastructure such as strong third-party grievance and reporting processes that bypass the direct manager are salient, the influence of ethical leadership may be attenuated. In contrast, a weak formal ethical infrastructure may heighten the influence of ethical leadership. Future research should combine the assessment of informal components, with formal components to gain a fuller understanding of the influence of ethical leadership at different levels on employee behavior and commitment. 


\section{CONCLUSION}

Increasingly society and communities are touting the importance of ethical leaders in business. Scholars also have asserted that despite considerable growth in research related to ethical leadership, more research is necessary given the importance of ethical leadership to organizations (Brown \& Mitchell, 2010). Yet, research furthering our understanding of how ethical leaders influence followers has been sparse (Brown $\&$ Mitchell, 2010). We responded to this call by examining not only the employee outcomes of ethical leadership but also the social psychological mechanisms by which it may have its influence. Our research demonstrates that ethical leadership has a significant influence on the regulatory mindsets of employees and the behaviors and commitments they experience in the work context. This contribution to understanding the influence of ethical leaders extends theory on ethical leadership, regulatory foci, and employee outcomes, but perhaps more importantly, it affirms the wisdom of those organizations that seek out, promote, and develop ethical leaders.

\section{REFERENCES}

Allen, N. J., \& Meyer, J. P. 1990. The measurement and antecedents of affective, continuance, and normative commitment to the organization. Journal of Occupational Psychology, 63: 1-18. http://dx.doi.org/10.1111/j.2044-8325.1990.tb00506.x

Arvey, R. D., \& Jones, A. P. 1985. The use of discipline in organizational settings: A framework for future research. Research in Organizational Behavior, 7: 367-408.

Avolio, B. J., \& Bass, B. M. 1988. Transformational leadership, charisma, and beyond. In J. G. Hunt, B. R. Baliga, H. P. Dachler, \& C. A. Schriesheim (Eds.), Emerging leadership vistas: 29-49. Lexington, Mass.: Lexington Books.

Bandura, A. 1986. Social foundations of thought and action: A social cognitive theory. Englewood Cliffs, N.J.: Prentice Hall.

. 1991. Social cognitive theory of self-regulation. Organizational Behavior and Human Decision Processes, 50: 248-87.

http://dx.doi.org/10.1016/0749-5978(91)90022-L

Bass, B. M., \& Steidlmeier, P. 1999. Ethics, character, and authentic transformational leadership behavior. The Leadership Quarterly, 10: 181-218.

http://dx.doi.org/10.1016/S1048-9843(99)00016-8

Bollen, K. A., \& Stine, R. 1990. Direct and indirect effects: Classical and bootstrap estimates of variability. Sociological Methodology, 20: 115-40. http://dx.doi.org/10.2307/271084

Borman, W. C., \& Motowidlo, S. J. 1993. Expanding the criterion domain to include elements of contextual performance. In N. Schmitt \& W. C. Borman (Eds.), Personnel selection in organizations: 71-98. San Francisco: Jossey-Bass.

Brockner, J., \& Higgins, E. T. 2001. Regulatory focus theory: Implications for the study of emotions at work. Organizational Behavior \& Human Decision Processes, 86(1): 35-66. http://dx.doi.org/10.1006/obhd.2001.2972 
Brown, M. E., \& Mitchell, M. S. 2010. Ethical and unethical leadership: Exploring new avenues for future research. Business Ethics Quarterly, 20(4): 583-616. http://dx.doi.org/10.5840/beq201020439

Brown, M. E., \& Treviño, L.K. 2006. Ethical leadership: A review and future directions. The Leadership Quarterly, 17: 595-616. http://dx.doi.org/10.1016/j.leaqua.2006.10.004

Brown, M. E., Treviño, L. K., \& Harrison, D. A. 2005. Ethical leadership: A social learning perspective for construct development and testing. Organizational Behavior and Human Decision Processes, 97: 117-34. http://dx.doi.org/10.1016/j.obhdp.2005.03.002

Cameron, K. 2006. Good or not bad: Standards and ethics in managing change. Academy of Management Learning \& Education, 5(3): 317-23. http://dx.doi.org/10.5465/AMLE.2006.22697020

Caza, A., Barker, B. A., \& Cameron, K. S. 2004. Ethics and ethos: The buffering and amplifying effects of ethical behavior and virtuousness. Journal of Business Ethics, 52: 169-78. http://dx.doi.org/10.1023/B:BUSI.0000035909.05560.0e

Choi, J. M. 2007. Change-oriented organizational citizenship behavior: Effects of work environment characteristics and intervening psychological processes. Journal of Organizational Behavior, 28: 467-84. http://dx.doi.org/10.1002/job.433

Ciulla, J. B. 1995. Leadership ethics: Mapping the territory. Business Ethics Quarterly, 5: 5-28.

Cohen, A. 2003. Multiple commitments in the workplace: An integrative approach. Mahwah, N.J.: Lawrence Erlbaum Associates.

Cooper-Hakim, A., \& Viswesvaran, C. 2005. The construct of work commitment: Testing an integrative framework. Psychological Bulletin, 131(2): 241-59. http://dx.doi.org/10.1037/0033-2909.131.2.241

Dansereau, F., Graen, G. B., \& Haga, W. 1975. A vertical dyad linkage approach to leadership in formal organizations. Organizational Behavior and Human Performance, 13: 46-78. http://dx.doi.org/10.1016/0030-5073(75)90005-7

De Hoogh, A. H. B., \& Den Hartog, D. N. 2008. Ethical and despotic leadership, relationships with leader's social responsibility, top management team effectiveness and subordinates' optimism: A multi-method study. The Leadership Quarterly, 19: 297-311. http://dx.doi.org/10.1016/j.leaqua.2008.03.002

Detert, J., Treviño, L. K., Burris, E., \& Andiappan, M. 2007. Managerial models of influence and counterproductivity in organizations: A longitudinal business unit-level investigation. Journal of Applied Psychology, 92: 993-1005. http://dx.doi.org/10.1037/0021-9010.92.4.993

Dierdorff, E. C. \& Morgenson, F. P. 2007. Consensus in work role requirements: The influence of discrete occupational context on role expectations. Journal of Applied Psychology, 92(5): 1228-41. http://dx.doi.org/10.1037/0021-9010.92.5.1228

Edwards, J. R., \& Lambert, L. S. 2007. Methods for integrating moderation and mediation: A general analytical framework using moderated path analysis. Psychological Methods, 12(1): 1-22. http://dx.doi.org/10.1037/1082-989X.12.1.1 
Fornell, C., \& Larcker, D. F. 1981. Evaluating structural equation models with unobservable variables and measurement error. Journal of Marketing Research, 18: 39-50. http://dx.doi.org/10.2307/3151312

Friedman, R. S., \& Förster, J. 2001. The effects of promotion and prevention cues on creativity. Journal of Personality \& Social Psychology, 81(6): 1001-13. http://dx.doi.org/10.1037/0022-3514.81.6.1001

Gao, L., Janssen, O., \& Shi, K. 2011. Leader trust and employee voice: The moderating role of empowering leader behaviors. The Leadership Quarterly, 22(4): 787-98. http://dx.doi.org/10.1016/j.leaqua.2011.05.015

Gerstner, C. R., \& Day, D. V. 1997. Meta-analytic review of leader-member exchange theory: Correlates and construct issues. Journal of Applied Psychology, 82: 827-44. http://dx.doi.org/10.1037/0021-9010.82.6.827

Ghoshal, S. 2005. Bad management theories are destroying good management practices. Academy of Management Learning and Education, 4: 79-91. http://dx.doi.org/10.5465/AMLE.2005.16132558

Giampetro-Meyer, A., Brown, T., Browne, M. N., \& Kubasek, N. 1998. Do we really want more leaders in business? Journal of Business Ethics, 17: 1727-36. http://dx.doi.org/10.1023/A:1006092107644

Graen, G. B., \& Scandura, T. A. 1987. Toward a psychology of dyadic organizing. Research in Organizational Behavior, 9: 175-208.

Graen, G. B., \& Uhl-Bien, M. 1995. Relationship-based approach to leadership: Development of leader-member exchange (LMX) theory of leadership over 25 years: Applying a multi-level multi-domain perspective. The Leadership Quarterly, 25: 219-47. http://dx.doi.org/10.1016/1048-9843(95)90036-5

Higgins, E. T. 1997. Beyond pleasure and pain. American Psychologist, 52(12): 1280-1300. http://dx.doi.org/10.1037/0003-066X.52.12.1280

1998. Promotion and prevention regulatory focus as a motivational principle. Advances in Experimental Social Psychology, 30: 1-41.

http://dx.doi.org/10.1016/S0065-2601(08)60381-0

2000. Making a good decision: Value from fit. American Psychologist, 55, 1217-30. http://dx.doi.org/10.1037/0003-066X.55.11.1217

Higgins, E. T., Roney, C. J. R., Crowe, E., \& Hymes, C. 1994. Ideal versus ought predilections for approach and avoidance distinct self-regulatory systems. Journal of Personality and Social Psychology, 66(2): 276-86. http://dx.doi.org/10.1037/0022-3514.66.2.276

Higgins, E. T., Shah, J., \& Friedman, R. S. 1997. Emotional responses to goal attainment: Strength of regulatory focus as moderator. Journal of Personality and Social Psychology, 72(3): 515-25. http://dx.doi.org/10.1037/0022-3514.72.3.515

Higgins, E. T., \& Silberman, I. 1998. Development of regulatory focus: Promotion and prevention as ways of living. In J. Heckhausen \& C. S. Dweck (Eds.), Motivation and self-regulation across the lifespan. New York: Cambridge University Press. http://dx.doi.org/10.1017/CBO9780511527869.005 
Higgins, E. T., \& Tykocinski, O. 1992. Self-discrepancies and biographical memory: Personality and cognition at the level of psychological situation. Personality and Social Psychology Bulletin, 18(5): 527-35. http://dx.doi.org/10.1177/0146167292185002

Hooper, D. T., \& Martin, R. 2008. Beyond personal leader-member exchange (LMX) quality: The effects of perceived LMX variability on employee reactions. The Leadership Quarterly, 19: 20-30. http://dx.doi.org/10.1016/j.leaqua.2007.12.002

Ilies, R., Nahrgang, J. D., \& Morgeson, F. P. 2007. Leader-member exchange and citizenship behaviors: A meta-analysis. Journal of Applied Psychology, 92: 269-77. http://dx.doi.org/10.1037/0021-9010.92.1.269

James, L., James, L., \& Ashe, D. 1990. The meaning of organizations: The role of cognition and values. In B. Schneider (Ed.), Organizational climate and culture: 40-84). San Francisco: Jossey-Bass.

Johnson, R. E., Chang, C., \& Yang, L. 2010. Commitment and motivation at work: The relevance of employee identity and regulatory focus. Academy of Management Review, 35(2): 226-45. http://dx.doi.org/10.5465/AMR.2010.48463332

Judge, T. A., Ilies, R. \& Scott, B. A. 2006. Work-family conflict and emotions: Effects at work and at home. Personnel Psychology, 59(4): 779-814. http://dx.doi.org/10.1111/j.1744-6570.2006.00054.x

Kalshoven, K., Den Hartog, D. N., De Hoogh, A. H. B. 2011. Ethical leadership at work questionnaire (ELW): Development and validation of a multidimensional measure. The Leadership Quarterly, 22(1): 51-69. http://dx.doi.org/10.1016/j.leaqua.2010.12.007

Kark, R., \& Van Dijk, D. 2007. Motivation to lead, motivation to follow: The role of the self regulatory focus in leadership processes. Academy of Management Review, 32: 500-28. http://dx.doi.org/10.5465/AMR.2007.24351846

Kenny, D. A., Kashy, D. A., \& Bolger, N. 1998. Data analysis in social psychology. In D. T. Gilbert, S. T. Fiske, \& G. Lindzey (Eds.), The handbook of social psychology, 4th ed.: 233-65). Boston: McGraw-Hill.

Kerr, S., \& Jermier, J. M. 1978. Substitutes for leadership: their meaning and measurement. Organizational Behavior and Human Performance, 22: 375-403. http://dx.doi.org/10.1016/0030-5073(78)90023-5

Klein, H. J., Molloy, J. C., \& Cooper, J. T. 2009. Conceptual foundations: Construct definitions and theoretical representations of workplace commitments. In H. J. Klein, T. E. Becker, \& J. P. Meyer (Eds.), Commitment in organizations: Accumulated wisdom and new directions. Mahwah, N.J.: Lawrence Erlbaum Associates.

Lanaj, K., Chang, C., \& Johnson, R. E. 2012. Regulatory focus and work-related outcomes: A review and meta-analysis. Psychological Bulletin, 138(5): 998-1034. http://dx.doi.org/10.1037/a0027723

LePine, J. A., \& Van Dyne, L. 2001. Voice and cooperative behavior as contrasting forms of contextual performance: Evidence of differential relationships with Big Five personality characteristics and cognitive ability. Journal of Applied Psychology, 86(2): 326-36. http://dx.doi.org/10.1037/0021-9010.86.2.326 
Liberman, N., Idson, L. C., Camacho, C. J., \& Higgins, E. T. 1999. Promotion and prevention choices between stability and change. Journal of Personality \& Social Psychology, 77(6): 1135-45. http://dx.doi.org/10.1037/0022-3514.77.6.1135

Marinova, S., Moon, H., \& Van Dyne, L. 2010. Are all good soldier behaviors the same? Supporting multidimensionality of organizational citizenship behaviors based on rewards and roles. Human Relations, 60(10): 1463-85. http://dx.doi.org/10.1177/0018726709359432

Mayer, D. M., Aquino, K., Greenbaum, R. L., \& Kuenzi, M. 2012. Who displays ethical leadership, and why does it matter? An examination of antecedents and consequences of ethical leadership. Academy of Management Journal, 55(1): 151-71. http://dx.doi.org/10.5465/amj.2008.0276

Mayer, D. M., Kuenzi, M., Greenbaum, R., Bardes, M., \& Salvador, R. 2009. How low does ethical leadership flow? Test of a trickle-down model. Organizational Behavior and Human Decision Processes, 108: 1-13. http://dx.doi.org/10.1016/j.obhdp.2008.04.002

Meyer, J. P. 2009. Commitment in a changing world of work. In H. J. Klein, T. E. Becker, \& J. P. Meyer (Eds.), Commitment in organizations: Accumulated wisdom and new directions. Mahwah, N.J.: Lawrence Erlbaum Associates.

Meyer, J. P., \& Allen, N. J. 1991. A three-component conceptualization of organizational commitment. Human Resource Management Review, 1: 61-89. http://dx.doi.org/10.1016/1053-4822(91)90011-Z

1997. Commitment in the workplace: Theory, research, and application. Thousand Oaks, CA: Sage.

Meyer, J. P., Becker, T. E., \& Vandeberghe, C. 2004. Employee commitment and motivation: A conceptual analysis and integrative model. Journal of Applied Psychology, 89(6): 991-1007. http://dx.doi.org/10.1037/0021-9010.89.6.991

Morrison, E. W. 2011. Employee voice behavior: Integration and directions for future research. The Academy of Management Annals, 5(1): 373-412. http://dx.doi.org/10.1080/19416520.2011.574506

Neubert, M. J., Carlson, D. S., Kacmar, K. M., Roberts, J. A., \& Chonko, L. B. 2009. The virtuous influence of ethical leadership behavior: Evidence from the field. Journal of Business Ethics, 90: 157-70. http://dx.doi.org/10.1007/s10551-009-0037-9

Neubert, M. J., Kacmar, K. M., Carlson, D. S., Chonko, L. B., \& Roberts, J. A. 2008. Regulatory focus as a mediator of the influence of initiating structure and servant leadership on employee behavior. Journal of Applied Psychology, 93(6): 1220-33. http://dx.doi.org/10.1037/a0012695

Organ, D. W., \& Konovsky, M. 1989. Cognitive versus affective determinants of organizational citizenship behavior. Journal of Applied Psychology, 7: 157-64. http://dx.doi.org/10.1037/0021-9010.74.1.157

Piccolo, R. F., \& Colquitt, J. A. 2006. Transformational leadership and job behaviors: The mediating role of core job characteristics. Academy of Management Journal, 49: 327-40. http://dx.doi.org/10.5465/AMJ.2006.20786079 
Piccolo, R. F., Greenbaum, R., Hartog, D. N., \& Folger, R. 2010. The relationship between ethical leadership and core job characteristics. Journal of Organizational Behavior, 31: 259-78. http://dx.doi.org/10.1002/job.627

Podsakoff, P. M., MacKenzie, S. B., Lee, Y., \& Podsakoff, N. P. 2003. Common method biases in behavioral research: A critical review of the literature and recommended remedies. Journal of Applied Psychology, 88: 879-903. http://dx.doi.org/10.1037/0021-9010.88.5.879

Podsakoff, P. M., MacKenzie, S. B., Paine, J. B., \& Bachrach, D. G. 2000. Organizational citizenship behaviors: A critical review of the theoretical and empirical literature and suggestions for future research. Journal of Management, 26(3): 513-63. http://dx.doi.org/10.1177/014920630002600307

Rubin, R. S., Dierdorff, E. C., \& Brown, M. E. 2010. Do ethical leaders get ahead? Exploring ethical leadership and promotability. Business Ethics Quarterly, 20(2): 215-36. http://dx.doi.org/10.5840/beq201020216

Salancik, G. 1977. Commitment is too easy! Organizational Dynamics, 6: 62-80. http://dx.doi.org/10.1016/0090-2616(77)90035-3

Scandura, T. A., Graen, G. B., \& Novak, M. A. 1986. When managers decide not to decide autocratically: Leader-member exchange and decision influence. Journal of Applied Psychology, 71: 250-56. http://dx.doi.org/10.1037/0021-9010.71.4.579

Scholer, A. A., \& Higgins, E. T. 2010. Regulatory focus in a demanding world. In R. H. Hoyle (Ed.), Handbook of personality and self-regulation: 291-314. Malden, Mass.: Blackwell.

Smith, C. A., Organ, D. W., \& Near, J. P. 1983. Organizational citizenship behavior: Its nature and antecedents. Journal of Applied Psychology, 68: 653-63. http://dx.doi.org/10.1037/0021-9010.68.4.653

Sobel, M. E. 1982. Asymptotic confidence intervals for indirect effects in structural equation models. In S. Leinhardt (Ed.), Sociological methodology 1982: 290-312. Washington, D.C.: American Sociological Association.

Sparrowe, R. T., Soetjipto, B. W., \& Kraimer, M. L. 2006. Do leaders' influence tactics relate to members' helping behavior? It depends on the quality of the relationship. Academy of Management Journal, 49(6): 1194-1208. http://dx.doi.org/10.5465/AMJ.2006.23478645

Tenbrunsel, A. E., Smith-Crowe, K., \& Umphress, E. 2003. Building houses on rocks: The role of the ethical infrastructure on organizations. Social Justice Research, 16: 285-307. http://dx.doi.org/10.1023/A:1025992813613

Thompson, J. A., \& Bunderson, J. S. 2003. Violations of principle: Ideological currency in the psychological contract. Academy of Management Review, 28: 571-86.

Treviño, L. K. 1992. The social effects of punishments in organizations: A justice perspective. Academy of Management Review, 17: 647-76.

Treviño, L. K., Brown, M., \& Hartmann, L. P. 2003. A qualitative investigation of perceived executive leadership in organizations: Perceptions from inside and outside the executive suite. Human Relations, 55: 5-37.

http://dx.doi.org/10.1177/0018726703056001448 
Treviño, L. K., Hartman, L. P., \& Brown, M. 2000. Moral person and moral manager: How executives develop a reputation for ethical leadership. California Management Review, 42(4): 128-42. http://dx.doi.org/10.2307/41166057

Van Dyne, L., \& LePine, J. A. 1998. Helping and voice extra-role behaviors: Evidence of construct and predictive validity. Academy of Management Journal, 41(1): 10819. http://dx.doi.org/10.2307/256902

Wallace, C., and Chen, G. 2006. A multilevel integration of personality, climate, selfregulation, and performance. Personnel Psychology, 59(3): 529-57.

http://dx.doi.org/10.1111/j.1744-6570.2006.00046.x

Walumbwa, F. O., Avolio, B. J., Gardner, W. L., Wernsing, T. S., \& Peterson, S. J. 2008. Authentic leadership: Development and validation of a theory-based measure. Journal of Management, 34: 89-126. http://dx.doi.org/10.1177/0149206307308913

Walumbwa, F. O., Mayer, D. M., Wang, P., Wang, H., Workman, K., \& Christensen, A. L. 2011. Linking ethical leadership to employee performance: The roles of leadermember exchange, self-efficacy, and organizational identification. Organizational Behavior and Human Decision Processes, 115: 204-13. http://dx.doi.org/10.1016/j.obhdp.2010.11.002

Walumbwa, F. O., \& Schaubroeck, J. 2009. Leader personality traits and employee voice behavior: Mediating roles of ethical leadership and work group psychological safety. Journal of Applied Psychology, 94: 1275-86. http://dx.doi.org/10.1037/a0015848

Wayne, S. J., Coyle-Shapiro, J. M., Eisenberger, R., Liden, R. C., Rousseau, D. M., \& Shore, L. M. 2009. Social Influences. In H. J. Klein, T. E. Becker, \& J. P. Meyer (Eds.), Commitment in organizations: Accumulated wisdom and new directions. Mahwah, N.J.: Lawrence Erlbaum Associates.

Weaver, G. R., Treviño, L. K., \& Cochran, P. L. 1999. Corporate ethics programs as control systems: Influences of executive commitment and environmental factors. Academy of Management Journal, 42: 41-57. http://dx.doi.org/10.2307/256873

Williams, L. J., \& Anderson, S. E. 1991. Job satisfaction and organizational commitment as predictors of organizational citizenship and in-role behaviors. Journal of Management, 17: 601-17. http://dx.doi.org/10.1177/014920639101700305

Williams, L. J., Cote, J. A., \& Buckley, M. R. 1989. Lack of method variance in selfreported affect and perceptions of work: Reality or artifact? Journal of Applied Psychology, 74: 462-68. http://dx.doi.org/10.1037/0021-9010.74.3.462

Wiltermuth, S. S., Monin, B., \& Chow, R. M. 2010. The orthogonality of praise and condemnation in moral judgment. Social Psychological and Personality Science, 1(4): 302-10. http://dx.doi.org/10.1177/1948550610363162

Wood, R., \& Bandura, A. 1989. Social cognitive theory of organizational management. Academy of Management Review, 14: 361-84.

Wu, C., McMullen, J., Neubert, M. J., \& Yi, X. 2008. The influence of leader regulatory focus on employee creativity. Journal of Business Venturing, 23: 587-602. http://dx.doi.org/10.1016/j.jbusvent.2007.09.005 